\title{
Comparing the evolution of national research policies: what patterns of change?
}

\author{
Benedetto Lepori, Peter van den Besselaar, Michael Dinges, \\ Bianca Potì, Emanuela Reale, Stig Slipersæter, Jean Thèves and \\ Barend van der Meulen
}

\begin{abstract}
This article presents a comparative analysis of the evolution of national research policies during the past three decades in six European countries (Austria, Italy, France, Netherlands, Norway and Switzerland), with a special focus on the changes of public project funding schemes. It systematically uses indicators on the volume of funding attributed by each instrument and agency, which have been developed in a project of the European network of excellence PRIME. A common model is identified in these countries, where project funding is the second main channel of public funding of research, but also there are considerable variations among them in the share of instruments and agencies, and in beneficiaries. There are three interesting commonalities: a strong increase of project funding volumes; a differentiation of instruments; and a general shift towards instruments oriented to thematic priorities. They also show that individual countries appear to follow quite distinct paths in the organisation setting of funding agencies, and that national differences in funding portfolios persist through time.
\end{abstract}

$\Lambda$ N IMPORTANT DEBATE in research policy studies in recent years has concerned the existence of (and the reasons for) similarities and differences among national research policies, particularly to what extent these policies have evolved in the last few decades in a similar direction and whether national specificities are keeping their importance.

Advocates of the convergence thesis have pointed to the globalisation of the economy and research systems, which confronts national research policies with similar issues to be addressed, and the importance of imitation effects in this context (isomorphism; Powell and di Maggio, 1983) and the normative pressure put by international organisations such as the Organisation for Economic Co-operation and Development (OECD) on the definition of policy objectives and measures (Lemola, 2002; Braun et al, 2003).

Since the 1990s, we should also consider the increasing role played by the European Union (EU)
Benedetto Lepori (corresponding author) is at Università della Svizzera italiana and Observatoire des Sciences et Techniques, via Lambertenghi 10a, 6904 Lugano; Email: blepori@unisi.ch; Tel: +41 5866646 14; Fax: +41 5866646 19. Prof Dr Peter van den Besselaar is research director of the Netherlands Centre for Science System Assessment, Rathenau Instituut, PO Box 95366, 2509 CJ Den Haag, The Netherlands; Email: p.vandenbesselaar@rathenau.nl; Tel: +31 70342 1542; Fax: +31 70 3633488. Michael Dinges is at the Joanneum Research Forschungsgesellschaft $\mathrm{mbH}$, Institute of Technology and Regional Policy, Haus der Forschung, Sensengasse 1, 1090 Wien, Austria; Email: michael.dinges@joanneum.at; Tel: +43 1 5817520 2813; Fax: +43 15817520 2820. Bianca Potì and Emanuela Reale are at CNR-CERIS, Via dei Taurini, 19, 00185 Rome, Italy. Emails: b.poti@ceris.cnr.it; e.reale@ceris.cnr.it;
Tels: +39 649937847; +39 6 49937853; Fax: +39 649937808 . Stig Slipersæter is NIFU-STEP, Wergelandsv. 7, N-0167 Oslo, Norway; Email: stig.slipersater@nifustep.no; Tel: +47 225951 81; Fax: +47 225951 01. Jean Thèves is Chargé d'études at the Observatoire des Sciences et Techniques, 93 rue de Vaugirard, 75006 Paris; Email: jean.theves@obs-ost.fr; Tel: +33 1443906 85. Barend van der Meulen is in Science, Technology, Health, and Policy Studies (STeHPS), School of Business, Public Administration and Technology, Twente University, PO Box 217, 7500 AE Enschede, The Netherlands; Email: b.j.r.vanderMeulen@wmw.utwente.nl; Tel: +31 534893906.

The authors thank the European Union through the PRIME network of excellence for funding this project. They also thank other people for their contributions, including Ghislaine Filliatreau, Philippe Larédo, Ruth Mampuys, Trude Røsdal. 
Benedetto Lepori obtained his degree in mathematical physics at the University of Rome in 1988 and a PhD in communication sciences at the University of Lugano in 2004 with a thesis on Swiss research policy. Since 1997, he has been responsible of the research office of the Università della Svizzera Italiana. His research interests cover Swiss higher-education and research policy, the production of S\&T indicators, especially concerning research funding and expenditure, and the introduction of new communication technologies in higher education. He is coordinator of the indicators activities in the PRIME network of excellence and chair of the PRIME indicators conference series.

Peter van den Besselaar is research director and head of the science system assessment department at the Rathenau Instituut. He is also a professor of communication science at the University of Amsterdam, with a special chair in e-social science. Previously, he was director of the Netherlands Social Science Data Archive (Steinmetz Archive) and an associate professor of social informatics at the University of Amsterdam. His current research interests are the dynamics of research fields, the development and change of the science system, science and innovation policy, (ICT-based) research infrastructures and the relation between science and technology and social change.

Michael Dinges is a researcher and project manager at Joanneum Research. Institute of Technology and Regional Policy in Vienna, where he is in charge of the thematic field 'Evaluations'. He graduated from the University of Vienna with a degree in economics and social sciences. His main areas of expertise are: evaluation methods; technology and innovation policy; S\&T indicators; and transition economics.

Bianca M Potì is researcher at CNR-Ceris. Her scientific interests are S\&T institutions and policy, and industrial and innovation economics. She is the responsible national in Create Acceptance (6th EU FP), in the Socrobust project 'Management tools and a management framework for assessing the potential of European long-term S\&T options'. Since 2005, she has been the scientific co-ordinator of a national three-year strategic project (FIRB Programme). Since 2002, she has been professor of industrial economics at the faculty of economics, University of Cassino. She delivers many presentations in international conferences and publishes in national and international journals.
Emanuela Reale is a senior researcher in science policy and law at CNR-CERIS of Rome. Her areas of interest are public research institutions and policies, indicators of S\&T, monitoring, evaluation and governance of the public research system, and public understanding of science. She is a member of the Executive Committee and Team leader for CERIS in the Network of Excellence PRIME 'Policies for Research and Innovation in the Move towards the ERA' (6th EU FP). She is teacher of institutions and research policies at the Scuola Superiore di Pubblica Amministrazione. She has published articles, books and delivered presentations at national and international level.

Stig Slipersæter has been a senior researcher at NIFU STEP since 1997. He graduated from the University of Oslo with a degree in sociology of science. Research interests include S\&T indicators in the domains of higher-education institutions, public and private research institutes, and human resources. He has also been analysing research policy and organisation of the research system, organisation of research institutes and highereducation institutions, and the internationalisation of research.

Jean Thèves obtained a degree in Physics at the University of Pau et Pays de l'Adour and a MD in History and Sociology of Science and Technology at the University Louis Pasteur in Strasbourg. He worked as a Scientific Deputy at the French Consulate in Toronto, Canada for three years. Since then, he has been a junior project manager at the Observatory of Science and Technology (OST), in Paris. His fields of interest are national systems of innovation, the production and analysis of S\&T indicators and research funding in higher-education institutions.

Barend van den Meulen is associate professor at the Department of Science, Technology, Health and Policy Studies (STeHPS) of the University of Twente. He is trained in chemistry and science and technology dynamics. In his research, recent advances in science and technology studies and in policy sciences are used to further understanding of science policy processes, to analyse the development of research systems and to advise governments and research organisations on science and technology policy. He has worked on the socioeconomic impact of science, the development of engineering sciences, the transition of research systems, and science and technology foresight. in defining the framework for a European research policy, benchmarking and proposing models for the policies of member countries, promoting cooperation among national initiatives, and through direct funding instruments such as the European Framework Programmes. This development is leading to considerable debate on future governance models for research and innovation policy in Europe (Kuhlmann, 2001).

Other authors have rather emphasised the profound differences in national policy styles and institutional structures in individual countries and their presumed impact on actors' choices in a context where most decisions are still taken at the national level and, concerning research, most of the funding for public research organisations comes from the national state (Elzinga and Jamison, 1995). As one of the few comparative studies on national research policy outlines, since national decision-makers are constrained by different institutional structures, they might adopt different answers to the same issues, even in a context of international interdependencies (Senker et al, 1999).
At the empirical level, existing comparative studies display a complex pattern where similarities and imitation among countries exist for some aspects (for example, concerning the main policy rationale and some funding instruments adopted) while for others differences between countries remain very large (consider, for example, the organisation of the public administration and funding agencies; Larédo and Mustar (2001); Braun et al (2003)).

However, in our view, a major limitation of this debate has been the lack of systematic comparisons between countries and across time based on welldefined measures. Almost all studies have been based on a subjective evaluation of policy documents or of characteristics of funding instruments, without trying to find a measure of their relative importance. This, in our view, is problematic, since we assume that changes in policies can also be realised by modifying the weight of instruments and not just by replacing them; thus it becomes essential to measure quantitatively the magnitude of changes.

In this paper, we systematically compare for six European countries (Austria, France, Italy, 
Netherlands, Norway and Switzerland) an important component of national research policies - the organisation of public project funding. Thus, we pursue three main objectives. First, we aim to measure similarities and differences between the countries considered quantitatively, concerning the overall volume of project funding, its share in public research funding, its composition by instruments and policy and objectives and the organisational forms used to allocate these funds.

Secondly, we will reconstruct the evolution of project funding over the last three decades and look at the common trends between the considered countries and country-specific evolutions. This will allow us to test empirically a number of hypotheses present in the literature concerning the increasing share of project funding in research public funding and its shift from responsive-mode instruments to more policy-oriented instruments, which is the third objective.

To this aim, we make use of a methodology that has been developed in the EU PRIME Network of Excellence to produce comparative indicators concerning public project funding based on the measure of the volume of funds granted each year by instrument and funding agency. Thus, the paper is also an example of how science and technology indicators can be designed and used for comparative purposes.

First, we define our object of study, the methodology and the data sources, and we introduce some theoretical categories useful for the comparison. We then provide a comparison of today's project funding systems in the six countries concerned. This is followed by a quantitative look at their evolution during the last 30 years and with some indications of specific national trajectories. Finally, some general lessons are drawn for comparative studies of research policies.

\section{Framework and research questions}

In today's research policy and funding systems, project funding can be considered as the second main allocation mechanism for public research funding alongside institutional funds attributed to universities and research organisations (Millar and Senker, 2000) and, in most European countries, it covers between a quarter and a third of total public research funds. Moreover, since World War II, it has been a choice mechanism used by governments to implement research policy and thus it is believed that instruments and allocation models for project funding reflect more directly political priorities than general funds (Braun, 2003; Guston, 1996). Hence, the relevance and the interest of studying project funding with the more general aim of understanding research policies in a comparative perspective.

A further feature making project funding suitable for comparative work is that the distinction between general and project funds is quite clear in most
European countries and the borderline cases are relatively limited; in fact, the only case in our sample where a more detailed discussion was needed is France (Thèves et al, 2007b, this issue). Thus, we are comparing a domain in research policy that can be delimited using similar criteria across countries.

\section{Project funding: delimitation and organisation issues}

We define project funding as money attributed to a group or an individual to perform a research activity limited in scope, budget and time, normally on the basis of the submission of a project proposal describing the research activities to be done. Whether the process of allocation is competitive or not is not decisive, since project funds can also be attributed through direct contracts. Thus this category includes research council projects, European framework programmes, and most technological funds and research contracts of ministries (for details on coverage, see Lepori et al, 2008).

In organisational terms, the decisive feature of project funding (as defined here) is the existence of some kind of agency selecting the project to be funded and allocating money to a research group. Examples are: research councils, agencies managed by the scientists themselves and enjoying considerable autonomy from the state (Braun, 1998); services and committees inside the different ministries (Sanz et al, 2005); technological agencies; international organisations such as the European Space Agency (ESA); and charities. We notice that, in this domain, delegation to quasi-independent agencies is widespread (Braun, 2003; 2006); hence the frequent use of the principal-agent theory to analyse funding agencies (Guston, 1996; Braun and Guston, 2003).

In many cases, funding agencies manage different instruments; this has become typical for research councils in some countries. This differentiation depends largely on multiple objectives attributed by the state to these agencies. This means also that in many cases delegation of project funding to an agency is bound by some conditions, such as programmes explicitly directed to specific research themes. The degree of autonomy of the agency might therefore vary according to the instrument considered (see Slipersæter et al, 2007, this issue). Also, joint management of programmes between the state and research council is present in some cases (such as the National Centres of Competence in Research in Switzerland; see Braun and Benninghoff (2003)).

We assume that each funding instrument possesses its specific objectives, rules and allocation mechanisms (either explicit or to some extent tacit). In some cases, these are directly related to the norms and objectives of the agency itself - as for academic instruments for research councils - while, in the case of research programmes managed by research councils, the objectives can be described as a compromise between those of the state and the agency (Shove, 2003). 
We are interested in measuring and comparing across countries the mix of funding instruments and the importance of different types of agency: this requires the development of suitable categories and typologies allowing a comparison across countries

While most of the literature in the field has concentrated on case studies concerning individual agencies and programmes (see, among others, van der Meulen, 2003; Braun and Benninghoff, 2003), we focus here on the comparison between countries concerning the whole portfolio of project funding. We focus on the role and characteristics of the funding agencies and on the type of funding instruments and programmes in place in each country (for example, objectives, allocation mechanisms, type of projects funded).

While qualitative comparisons are important, for example, among lists of instruments, we systematically use data on funding volumes as a proxy to measure the importance of the different instruments. Thus, we are interested in measuring and comparing across countries the mix of funding instruments and the importance of different types of agency (for example, research councils vs ministries). This requires the development of suitable categories and typologies allowing a comparison across countries.

\section{Historical evolution and patterns of change}

Like research policies, funding systems evolve over time and there is a large body of (essentially qualitative) literature on the subject. At a general level, this literature identifies two main changes: a shift in the delegation modes of funding allocation from blind delegation to the scientific community, to the research councils, to more responsive modes where the state sets more specific targets (for example, concerning priority domains or research structures (Braun, 2003; Potì and Reale, 2007, this issue); and a shift in the general objectives from support to academic science to support to research oriented to social and economic needs, linked to the evolution of the overall models of research policy from 'science push' to policies oriented to social relevance and later to economic innovation (Brooks, 1986; Elzinga and Jamison, 1995; Guston, 2000).

Concerning project funding, it is normally assumed that the share of project funding has increased at least since the beginning of the 1980s (Geuna, 2001; OECD, 2003). Moreover, it is assumed that these trends implied a shift from reactive instruments funding academic research, to instruments where the research subjects or domains are predefined by the state, possibly in co-operation with the economy. Thus, we witness the emergence of programmes oriented to socio-political needs in the 1970s (Research Applied to National Needs (RANN) in the USA, National Research Programmes in the Netherlands and in Switzerland) and of technology programmes in the 1980s, including the launch of the European Framework programmes (Caracostas and Muldur, 2001).

Also, changes have been documented in the agencies managing project funding: research ministries acquiring a role in project funding in some countries (Italy, Germany); the emergence of the EU as a major player in project funding; and changes in the role and organisation of research councils in many countries (van der Meulen, 2003; Godin et al, 1999). It is generally acknowledged that the 'new' funding instruments have been created alongside the existing ones, rather replacing them (Braun, 2003) and thus that, generally, different 'funding styles' might coexist in research policy (Benner and Sandström, 2000).

However, there are two major limitations of these studies. First, most of them are based on the analysis of an individual case at country or even agency level and thus the possibility of generalising them has to be carefully discussed. Secondly, concerning project funding there is a remarkable lack of quantitative indicators and thus theses such as the increase of the share across time cannot easily be verified empirically (Lepori, 2006a; Lepori et al, 2008); for instance, we do not have any comparable information concerning the quantitative importance of this mode of allocation between countries. This is a major problem especially for historical analysis.

In this context, our objective will be to provide fairly comprehensive descriptions of project funding systems in the six countries considered for the last three decades (focusing on the years 1970, 1980, 1990, 2002) and to complete them with data on the funding volume for each instrument. This will allow us to examine empirically both the evolution of project funding volume and its composition by agencies and instruments and to look quantitatively at common trends and national specificities.

\section{National and multi-level embeddedness}

Institutional embeddedness is a classical argument in organisational analysis and socio-economics (Granovetter 1985; Hollingsworth 2002a). In its widest sense, it refers to the fact that actors are embedded in complex institutional environments that not only constrain, but largely shape, them and thus generate regularities of actors and actor's behaviour at the macro-level (Hollingsworth, 2002a). It is important to distinguish between types of institutional arrangement, such as social norms and rules, that 
characterise societies as a whole and display the highest level of stability, and general co-ordination mechanisms of a society such as markets and state and institutional arrangements specific to a domain, fro instance, the design of research policy and its organisational structure (Braun et al, 2003). For our discussion, this implies that the behaviour of actors in research policy is influenced also by institutional arrangements outside this domain; these are likely to be society or country-specific, so it is not possible to compare research policies without considering also the wider societal framework in which these policies are embedded and its differences across countries.

Moreover, in modern society, institutional embeddedness is intrinsically multi-level, in the sense that institutional arrangements at different spatial levels - global, macro-regional, country, regional and so on - are intertwined in a complex way (Hollingsworth, 2002b). Thus, some of the institutional arrangements relevant for research policy can be assumed to be largely global, such as the economy in high-tech domains or scientific and technological developments in many areas of natural and technical sciences or rationales and norms of research policy diffused by the OECD. Others are situated at the European level, for instance, some economic regulations, the general political and normative framework of the European Research and Higher Education Area and funding programmes such as the European Framework Programmes. Some very relevant arrangements for research policy are clearly national, including the organisation of the political system and of the public research system (Kuhlmann, 2001).

Therefore, we must assume that the behaviour of actors in research policy is influenced at the same time by country-level and by wider-level institutional arrangements. Moreover, the importance of these institutional levels varies among the types of actors considered. For example, it is well-known that large multinational companies tend to develop global research strategies (Kuhlmann, 2001; Meyer-Kramer and Reger, 1999), while at least in the European context the frame of reference for public research organisations is still largely national.

In this context, we assume that an explanation of the similarities and differences among countries concerning public project funding cannot focus only on a single institutional arrangement, for example, international policy rationales or national political organisation. Rather it has to take into account this multiple embededdness in different realms of social life and in different institutional levels (international, European, national).

\section{Path dependency and evolution of research policies}

Path dependency is a general argument that has been widely used in the study of economic and technological development (North, 1990; Arthur, 1994) in political science (Pierson 2000) and in historical sociology (Mahoney 2000). In its broadest sense, it means that today's configuration of a system depends on its history and thus cannot be understood by looking at today's state only. In a narrower sense, path dependency has been used for the "historical sequences process in which contingent events set into motion institutional patterns or event chains that have deterministic properties" (Mahoney, 2000). This means that, while the initial events are largely unpredictable for their singular nature, they select a specific path that is stable and separated from alternatives routes that might have been taken.

In the analysis of technological innovation, the rationale for path dependency has been sought in increasing returns and in the irreversibility of technological investments, which imply high switching costs, even if the chosen alternative is not necessarily the most efficient one in the long run (David, 1985; Dosi, 1982; Arthur, 1994). Similar arguments have been put forward in institutional analysis to explain, for example, path dependency in economic organisation of countries (North, 1990) and, in general, in political life (Pierson, 2000). We notice that these arguments go beyond the classical claim for institutional stability (Hollingsworth, 2002a; Scott, 2001), since they imply also that the future evolution of the system is largely determined by its history.

This argument raises a number of issues of interest for our analysis. These concern first the degree of stability of existing institutional arrangements and differences in this respect among countries, according to, for example, the organisation of their political systems or their history (including rupture events such as wars or changes of regime). For instance, our sample includes countries that have undergone a change of political regime during the last century, such as France and Italy, and countries, such as Switzerland, keeping basically the same political structure.

Secondly, there is the possibility of stable institutional arrangements that orient national research policies and funding systems over a long period of time and keep them different from other countries, even if faced with similar external pressures. For example, long-term work on the German innovation systems shows a high degree of stability of its technological specialisation since the 19th century (Grupp et al, 2004; Dominguez Lacasa et al, 2003) and thus gives some evidence that components of the national innovation system might be so stable as to survive major historical changes. Correspondingly, we are interested in the conditions and occurrences of ruptures and the conditions and mechanisms that enable actors to 'break the path' and to push research policy in a new trajectory (possibly by making use of hidden alternatives or by transferring experiences from other countries (Crouch and Farrell, 2004)).

Finally, there is the importance of the initial structuration phase of new organisational fields - in our case of national research policies and public funding 
systems - where it is reasonable to expect that actors had more freedom to shape institutional settings and their effects on today's systems. This subject has been examined repeatedly in other domains such as education or healthcare (Meyer et al, 1988; di Maggio, 1991; Scott et al, 2000), but quite rarely in research policies for the lack of suitable comparative information.

While in this paper we provide some quantitative information comparing the evolution of project funding in the considered countries, many of these issues will also be discussed more in-depth in the following papers (see Slipersæter et al, 2007; Potì and Reale, 2007; Thèves et al, 2007b: all this issue).

\section{Methodology and data sources}

Even if, in institutional and organisational terms, project funding appears to be relatively well-defined, the collection of comparable data proved to be a complex exercise. Our approach was based on the production of national lists of instruments to be included and on the collection from the funding agencies themselves of data on the amount allocated each year. Moreover, for each of the six countries involved, a detailed report has been produced, containing qualitative descriptions of research funding systems, standard description of funding instruments and, finally, charts of flows for the years 1970, 1980, 1990 and 2002 (Dinges, 2005; Lepori, 2005; Potì and Reale, 2005a; Slipersæter, 2007; Thèves et al, 2007a; van den Besselaar et al, 2007). The reader should refer to Lepori et al, 2007 for a detailed discussion of methodological choices and problems which emerged.

The main difficulties in this work have been the definition of a comparable list of instruments, the calculation of amounts in some cases (for example European funding) and, most of all, the reconstruction of time series. We have adopted a broad approach, extending the scope of project funding beyond individual grants and projects to include also more long-term schemes such as centres of excellence if allocated competitively and for a limited period of time (for example eight to ten years).

\section{Project funding appears to be relatively well-defined but the collection of comparable data proved to be complex: the main difficulties were in the definition of a comparable list of instruments, the calculation of amounts in some cases and, most of all, the reconstruction of time series}

Moreover, we have included also technological development programmes even if to some extent they probably finance also activities outside R\&D (as in the case of European Space Agency). In the Dutch case, we also included charities, which are a significant source of project funds in the medical sector. A further major issue has been the definition of categories for the comparative analysis concerning agencies and instruments; the classification we present proved to be more or less usable, but the reader should be aware that not all instruments fit very well into the defined categories.

The only country where the basic categories proved not to be fully usable was France, where a large part of public funds is allocated through the CNRS (Centre National de la Recherche Scientifique) to the joint CNRS/universities laboratories. These funds present some characteristics similar to project funding since they contain a competitive element through the labelling of the laboratories, but they display some very important differences (primarily, allocation is given in the form of CNRS personnel rather than of money). We thus provide two sets of data for France, including and excluding these funds and a detailed discussion in a separate paper in this issue (Thèves et al, 2007b, this issue).

The methodology has proved to be usable for constructing time series over the last 30 years, since it has been possible to retrieve data on the funding volume for most instruments. However, as for most long-term time series (Grupp et al, 2004; Dominguez Lacasa et al, 2003), we were faced with a number of consistency problems, including: validating older data (since we make heavy use of non-statistical sources); identifying the existing instruments; and, most of all, classifying correctly the instruments, since some of them might have changed their rules over time.

Also, since project funding data were not systematically collected in the past, we observed wide variations across time in the quality and detail of the available data. For example, in Norway, quite detailed data exist on Government funding for a tenyear period in the 1970s/1980s, but this series stops later. In Switzerland, project funding data have been systematically collected for the years from 1988 to 1999 by the Swiss Science Council, but later data have to be compiled from different sources.

For the Netherlands, reliable data on project funding are available only from 1975 onwards. From 2000, data on project funding become extremely complex, because of new funding instruments that combine different types of funding (institutional, project and private) and that are not clearly administered in the national budgets.

These changes in data sources and availability might well impact on the reconstructed series. Thus, while we believe that the analysis that follows correctly depicts the main trends, the reader should be aware that these data cannot be used for further analysis without validation and cross-checking with other information. 


\section{Public project funding: a comparative view}

In this section, we compare the organisation of project funding for the six countries participating in the project for the baseline year 2002. These countries are not fully representative of the European situation, especially because they do not include countries such as Germany and the UK, but they do represent an interesting sample covering most of western Europe.

Table 1 shows some data on the overall level of project funding compared to the total government budgetary appropriations or outlays for $R \& D$ (GBAORD) (OECD, 2002) and to gross domestic product (GDP). For France, we provide two different figures, including and excluding the CNRS allocation to joint laboratories (Thèves et al, 2007b, this issue).

Overall, the differences among the countries are more gradual than fundamental: in all, the examined countries project funding plays a significant role in public research funding, but in none of them does it appear to be the dominant mode of allocation of resources; this is even though we are considering quite different countries in terms of their size, organisation of the research system and science productivity indicators. We are identifying here a regularity that seems to characterise European countries and differentiates them from the US situation, where institutional funds account for only about $20 \%$ of the R\&D funding in academic institutions (National Science Foundation, 2003).

\section{Organisation and funding instruments}

When we analyse the portfolio of funding instruments, the managing agencies and the categories of beneficiaries, the differences among the countries emerge more clearly.

Role of managing agencies For the managing agencies, we used a simple classification between national government administration (ministries and programme committees inside the different ministries), intermediary agencies with high autonomy from the state (research councils, but also some technological agencies and charities) and international organisations, including the European Union and the European Space Agency. We notice that some borderline cases exist, for example, concerning innovation agencies, where it is not always clear whether to classify them as intermediaries or as committees in the economic ministries.

The pattern we see in Figure 1 is of very strong differences among countries in the organisational structures and role of agencies. In Italy, intermediaries are practically absent and project funding is managed directly by the research ministry (Potì and Reale, 2005b), a situation that seems also to characterise other Mediterranean countries such as Spain and Portugal (Sanz et al, 2005).

Four countries have research councils, but with different roles and quantitative importance. Two of them (Austria and Switzerland) have maintained most features of the academic-driven model essentially providing funding in responsive mode, while, since its merger in the 1990s, the Research Council of Norway has been transformed into a multipurpose funding agency with a larger palette of instruments, including some devoted to technological innovation (Slipersæter et al, 2007, this issue). The Dutch Research Council seems to represent an intermediary case, with responsive mode alongside thematic programmes.

A large independent innovation agency exists in Austria. There is a large agency for innovation policy in the Netherlands, and a smaller one in Switzerland, but these are not autonomous. In this paper, the instruments it manages are accounted as governmental project funding. Accordingly, the role of project funding managed by the ministries varies: it is dominant in Italy and important in Norway, Netherlands and France, while it is more limited in Switzerland and Austria.

Finally, in France, intermediary funding agencies stricto sensu play a rather limited role (with the exception of the space sector), while most project funding is managed by the ministries, but the CNRS takes some of their functions using a very specific funding model for joint laboratories through allocation of human resources (see Thèves et al, 2007b, this issue).

Instrument types The mapping and classification of instrument types proved to be more difficult because of their multidimensionality and because a number

Table 1. Basic data, 2002

\begin{tabular}{lccc}
\hline Country & $\begin{array}{c}\text { Total project funding } \\
\text { (millions current PPP \$) }\end{array}$ & $\begin{array}{c}\text { Total project funding } \\
\text { (\% of GBAORD) }\end{array}$ & $\begin{array}{c}\text { Total project funding } \\
\text { (\% of GDP) }\end{array}$ \\
Austria & & & 0.20 \\
France & 495 & 31 & 0.20 \\
France (with CNRS) & 3,459 & 20 & 0.31 \\
Italy & 5,262 & 31 & 0.16 \\
Netherlands & 2,467 & 24 & 0.33 \\
Norway & 1,448 & 33 & 0.32 \\
Switzerland & 529 & 42 & 0.19 \\
\hline
\end{tabular}

Sources: OECD except project funding data (produced in this study) Italy: GBAORD data 2001 


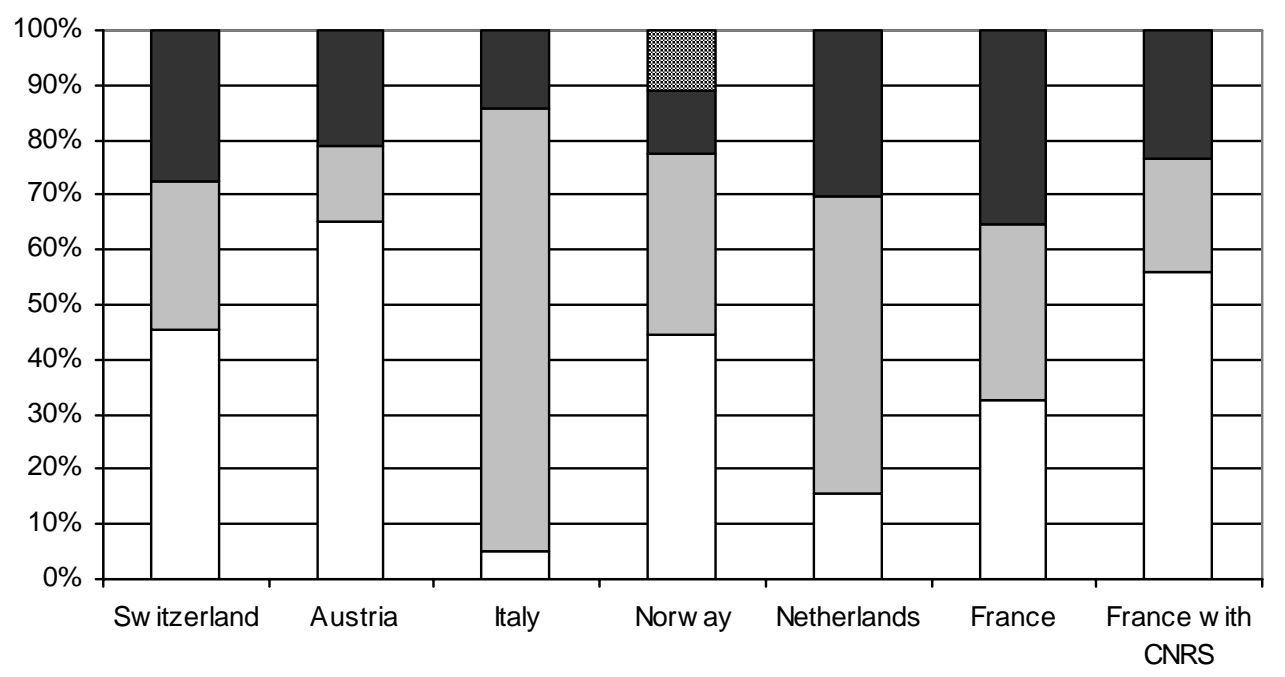

$\square$ Intermediaries $\square$ Government $\square$ International $\square$ Undivided

Figure 1. Role of managing agencies, 2002

Notes: International: EU FP and European Space Agency contracts

Intermediaries: Austria: Austrian Science Fund and Austrian Innovation Agency; Italy: Italian

Space Agency and National Research Council; Switzerland: Swiss National Science

Foundation; Netherlands: Netherlands Organization for Scientific Research (NWO) and

Charities; Norway: The Research Council of Norway; France: ANVAR, CNES, CIFRE, ANRS,

ADEME and CNRS.

Government: all other funding schemes

of instruments are, at the level of aggregation considered here, rather heterogeneous. We resorted to a classification distinguishing two specific cases academic-oriented instruments mostly in responsive mode and innovation-oriented instruments - alongside a more heterogeneous set of instruments where themes are defined from the beginning.

The first relevant remark is that practically all cases in Table 2 are filled, except for the space domain, which small countries have delegated almost completely to the European Space Agency. Thus, the small size of a country appears to matter, since it favours the delegation of domains requiring largescale facilities, such as space, nuclear energy, particle physics, to international organisations. With this exception, the countries examined have developed similar policy mixes, where the production of basic knowledge, social relevance and economic

Table 2. Classification of instruments by country

\begin{tabular}{|c|c|c|c|c|}
\hline Country & Academic & Innovation & Thematic general & Space \\
\hline International & $\begin{array}{l}\text { European Research Council } \\
\quad \text { (from 2007) }\end{array}$ & & EU FP & ESA \\
\hline Austria & $\begin{array}{l}\text { Austrian Science Fund; some } \\
\text { grant programmes of the } \\
\text { Federal Ministry }\end{array}$ & $\begin{array}{l}\text { General programmes of the } \\
\text { Austria Research } \\
\text { Promotion Agency }\end{array}$ & $\begin{array}{l}\text { Programmes of ministries } \\
\text { Thematic programmes of the } \\
\text { Austria Research } \\
\text { Promotion Agency }\end{array}$ & $\begin{array}{l}\text { Aerospace programme } \\
\text { (Austria Research } \\
\text { Promotion Agency) }\end{array}$ \\
\hline France & $\begin{array}{l}\text { FNS; Doctoral Grants from } \\
\text { research ministry; FRT } \\
\text { (RRIT), PHRC, ANRS; } \\
\text { CNRS (if included) }\end{array}$ & ANVAR & $\begin{array}{l}\text { Programmes from Ministries } \\
\text { of Industry/Defence }\end{array}$ & CNES \\
\hline Italy & COFIN; FIRB; CNR & FAR; FIT; L488 & $\begin{array}{l}\text { Mismez; Fisr; Pus; Maf; Mis; } \\
\text { Pon; } \\
\text { Cnr finalised projects }\end{array}$ & ASI \\
\hline Netherlands & $\begin{array}{l}\text { Most National Research } \\
\text { Council NWO programmes }\end{array}$ & $\begin{array}{l}\text { A variety of programmes, } \\
\text { mainly through the Ministry } \\
\text { of Economic Affairs }\end{array}$ & $\begin{array}{l}\text { NWO thematic programmes; } \\
\text { policy-oriented research } \\
\text { funds of ministries }\end{array}$ & $\begin{array}{l}\text { Several national programmes } \\
\text { for space research }\end{array}$ \\
\hline Norway & $\begin{array}{l}\text { RCN free projects, grants, } \\
\text { basic research programmes } \\
\text { and centres of excellence }\end{array}$ & $\begin{array}{l}\text { RCN user-directed } \\
\text { innovation programmes } \\
\text { and centres for research- } \\
\text { based innovation }\end{array}$ & $\begin{array}{l}\text { RCN Large Scale } \\
\text { Programmes and Targetede } \\
\text { programmes } \\
\text { National administration } \\
\text { contracts }\end{array}$ & \\
\hline Switzerland & $\begin{array}{l}\text { SNF free research projects; } \\
\text { grants; National Centres } \\
\text { of Excellence }\end{array}$ & $\begin{array}{l}\text { CTI projects (including } \\
\text { Eureka) }\end{array}$ & $\begin{array}{l}\text { National Research } \\
\quad \text { Programmes } \\
\text { Priority Programmes } \\
\text { National and regional } \\
\text { administration contracts }\end{array}$ & \\
\hline
\end{tabular}




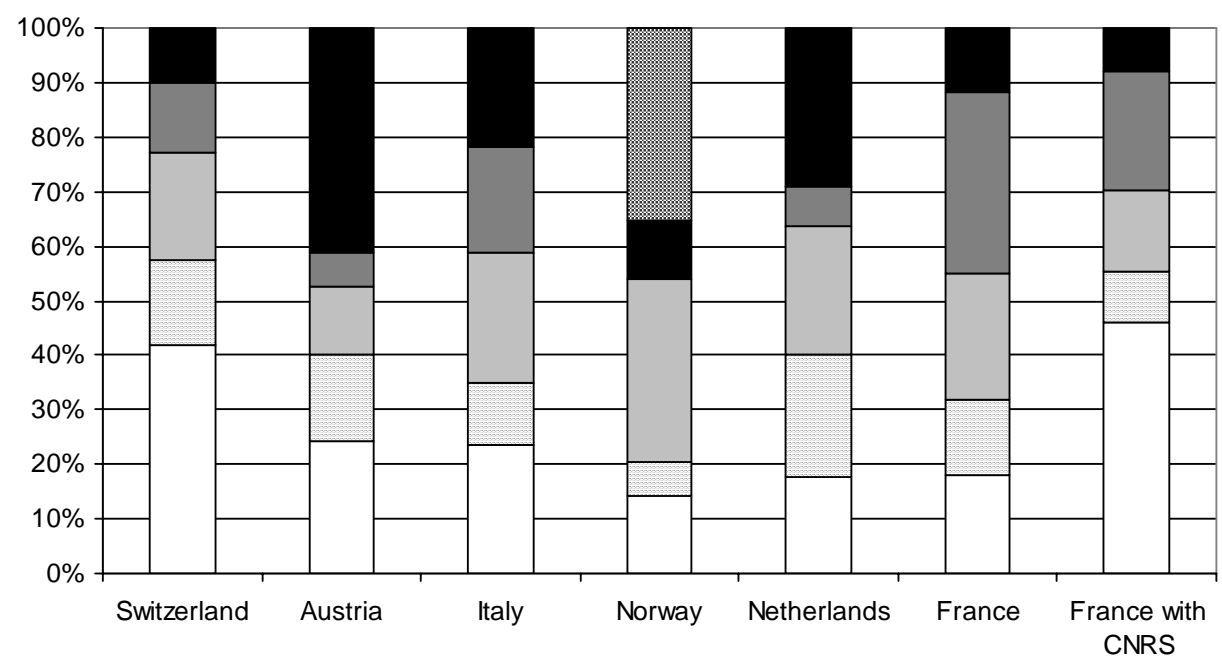

$\square$ Academic $\square$ EU FP $\square$ Thematic national $\square$ Space (ESA + national programs) $\boldsymbol{\square}$ Innovation $\square$ Undivided

Figure 2. Share of instrument types, 2002

innovation are promoted through specific instruments. We could then speak of a 'composite policy model' trying to find a balance among the different rationales for public support to research.

When considering the quantitative importance of the instrument types, more significant differences among countries emerge (see Figure 2). For example, even excluding the very specific French case, the share of academic instruments varies from more than $40 \%$ for Switzerland to little more than $20 \%$ for Austria, Italy and Norway. Innovation-oriented instruments account for $40 \%$ of the total in Austria, 20\% in Italy, 17\% in Norway, but less than $10 \%$ in France and Switzerland. Some national specificities emerge, for instance, the very strong role of space research in France and the use of thematic national programmes in Norway.

Thus, while the ingredients of project funding are largely the same, the weight given to the different components seems to depend largely on countryspecific factors. We notice that this classification is related to the labelling of instruments and to policy intentions, but not necessarily to the research performed; for example, thematic national programmes in Norway and Switzerland can partly function as an academic instrument even if the overall structuring principle is thematic. Thus, while we believe that national differences are real, their exact importance might well depend on the classification scheme used (see also Potì and Reale, 2007, this issue).

Shares of beneficiaries A further important aspect is to look at beneficiaries and, especially, the relative share of funds received by public vs private performers (Figure ).

In this case also, differences are rather large, since the share of project funds to private companies ranges between 19\% in Switzerland (being mostly international funds) and 55\% in Italy. In this respect, national specificities appear to be the most important explaining factor. Thus, Switzerland has a research

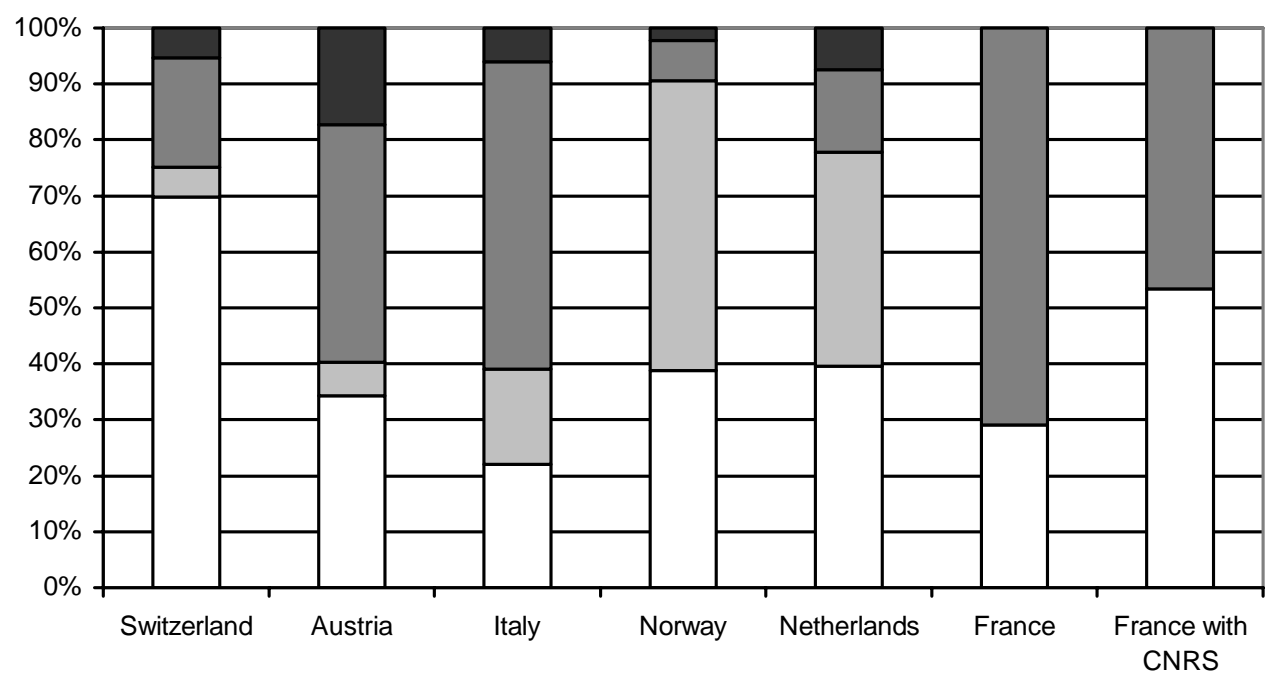

$\square$ Higher education $\square$ PRO $\square$ Private $\square$ Undivided

Figure 3 Shares of beneficiaries, 2002

Note: $\quad$ For France, higher education also includes PRO since no separation is possible 
policy model that assumes that the state should not directly finance industrial R\&D; this model has survived strong pressure from the OECD during the 1980s (Lepori, 2006a). On the other hand, in the Italian case, project funding has been a choice instrument to support private research activities in a context in which private investments are much lower than in other countries.

Norway is also a very specific case, since there is a large sector composed of research institutes, mostly oriented towards applied research; about half the research performed is for industry-relevant purposes, financed by industry and is included in the private sector in the R\&D statistics. This goes a long way to explaining the low share of the private sector in our data, since we consider the research institutes separately. The Netherlands displays a clear separation, with the universities receiving project funding essentially from the Research Council and a large number of missionoriented research institutes mostly funded by ministries through specific programmes. The relatively high level of "undivided" refers to the growing support for schemes for university-industry-public research organisation (PRO) collaborations.
France is a case for strong direct support to the private sector, both in absolute and relative terms; in fact, France has a tradition of direct support to public companies through large technological programmes, which have been progressively replaced in the last two decades by project funding instruments (Mustar and Larédo, 2002; Thèves et al, 2007b, this issue). Hence, we can conclude that national specificities, both in the overall model concerning public intervention in the private economy (for example the 'colbertist' model in France or the liberal model in Switzerland) and specificities of the national research systems are stronger than international tendencies in determining the degree of support for private research.

\section{A summary view and some conclusions}

Table 3 summarises some of the main features of the project funding model in the countries considered.

In our view, these results support an interpretation based on the combination of two main components. First, we find a set of rationales, policy models and instruments specific to research policy that is largely

Table 3. Comparison of national project funding systems (2002)

\begin{tabular}{|c|c|c|c|}
\hline Country & Funding instruments & Managing authority & Beneficiaries \\
\hline Austria & $\begin{array}{l}\text { A balanced portfolio with a large } \\
\text { instrument for academic research, a } \\
\text { large instrument for industrial research } \\
\text { aiming at research geared towards } \\
\text { innovation and a set of thematic } \\
\text { programmes }\end{array}$ & $\begin{array}{l}\text { Two main agencies, one for the } \\
\text { academic research, and one for } \\
\text { innovation and thematic purposes } \\
\text { (since 2004) manage most of the } \\
\text { project funds }\end{array}$ & $\begin{array}{l}\text { A balanced portfolio, when neglecting } \\
\text { the European Framework Programme for } \\
\text { which accounting to beneficiaries was } \\
\text { difficult }\end{array}$ \\
\hline France & $\begin{array}{l}\text { Two sets of instruments: project } \\
\text { funding in thematic programmes or } \\
\text { innovation for the companies; allocation } \\
\text { of funds through human resources in } \\
\text { the public sector }\end{array}$ & $\begin{array}{l}\text { Ministries play a very strong role in } \\
\text { technological programmes, alongside } \\
\text { the Agency for Innovation (ANVAR); } \\
\text { CNRS as the dominant player in the } \\
\text { public sector }\end{array}$ & $\begin{array}{l}\text { Project funding directed mostly to } \\
\text { private companies, human resources } \\
\text { funding the public sector }\end{array}$ \\
\hline Italy & $\begin{array}{l}\text { Instruments oriented at technological } \\
\text { innovation in companies and policy- } \\
\text { oriented programmes are most } \\
\text { important; the ministry has some } \\
\text { instruments oriented to academic } \\
\text { research }\end{array}$ & $\begin{array}{l}\text { Most project funds are managed directly } \\
\text { by ministries through ad hoc committees; } \\
\text { the role of intermediaries is marginal }\end{array}$ & $\begin{array}{l}70 \% \text { of funds benefit to private } \\
\text {; companies; the share of universities is } \\
\text { below } 15 \%\end{array}$ \\
\hline Norway & $\begin{array}{l}\text { A heterogeneous set of instruments for } \\
\text { both small-scale and large-scale } \\
\text { academic research, for funding of } \\
\text { thematic programmes mainly at PROs, } \\
\text { and some instruments directed towards } \\
\text { innovation in industry }\end{array}$ & $\begin{array}{l}\text { Intermediary organisation (Research } \\
\text { Council of Norway) dominant at national } \\
\text { level since it funds all domains, including } \\
\text { innovation and thematic programmes; } \\
\text { some programmes funded by ministries } \\
\text { are also managed by RCN, while some } \\
\text { ministries operate their own thematic } \\
\text { programmes and a project portfolio }\end{array}$ & $\begin{array}{l}\text { Small part of funding directed towards } \\
\text { industry; the role of research institutes } \\
\text { (public and private) is more dominant }\end{array}$ \\
\hline Netherlands & $\begin{array}{l}\text { A balanced mix between thematic } \\
\text { instruments, academic instruments and } \\
\text { innovation-oriented instruments }\end{array}$ & $\begin{array}{l}\text { The research council takes the } \\
\text { dominant role for academic funding, } \\
\text { while some sector ministries have large } \\
\text { thematic programmes in their domains }\end{array}$ & $\begin{array}{l}\text { Universities receive project funding from } \\
\text { the research council; thematic } \\
\text { programmes can be oriented to } \\
\text { universities and to PROs; direct funding } \\
\text { of private companies is limited }\end{array}$ \\
\hline Switzerland & $\begin{array}{l}\text { At national level academic instruments } \\
\text { account for the largest share of funds, } \\
\text { but there are also some policy-oriented } \\
\text { instruments; innovation-oriented } \\
\text { instruments are limited to co-operative } \\
\text { projects with HEl and to some } \\
\text { international programmes (especially } \\
\text { European Space Agency) }\end{array}$ & $\begin{array}{l}\text { Intermediary organisation (Swiss } \\
\text { National Science Foundation) dominant } \\
\text { at national level and taking also the } \\
\text { management of policy-oriented } \\
\text { programmes; the only significant } \\
\text { competition comes from European union } \\
\text { programmes; role of the ministries is } \\
\text { marginal }\end{array}$ & $\begin{array}{l}\text { Three-quarters of all project funds } \\
\text { benefit the higher-education sector; if we } \\
\text { exclude European Space Agency Funds } \\
\text { the share of private companies is very } \\
\text { small }\end{array}$ \\
\hline
\end{tabular}




\section{The choice of the mix of objectives, instruments and beneficiaries depends \\ to a large extent on national specificities: thus, inside the space defined by the internationally accepted model of research policy, each country is able to define its own profile}

the same for all countries considered. This includes: the use of project funding as the second channel for allocation of public research funding, thus it has a significant share, but is not the predominant mode of allocation; the identification of three major rationales for the allocation of funds (the development of scientific knowledge, the resolution of social and political problems and economic development); and the set-up of the corresponding instruments (with many similarities among countries in their labelling, but also in their organisation).

However, the choice of the mix concerning objectives, instruments and beneficiaries depends to a large extent on national specificities, for example, concerning the degree of the intervention of the state to support private research. Thus, inside the space defined by the (internationally accepted) model of research policy, each country is able to define its own profile.

Finally, the organisational structure for the allocation of project funding appears to be completely specific to each country and, as we shall see later, is largely dependent on the history. Thus, even in our limited sample we find countries with an academicoriented research council (Switzerland and Austria) alongside an innovation agency, countries with a generalist research council (Norway) and a case where project funding is managed directly by the ministry (Italy), a country with both a strong academic council and a strong innovation-oriented ministry (Netherlands), not to speak of the very specific French model with the CNRS taking on some of the functions of a funding agency.

\section{International tendencies, national trajectories}

The available data allow a reconstruction of the main changes in the project funding during the last 30 years in the six countries considered. We follow the same procedure as in the previous section, by first looking at changes in the overall level, then the portfolio of instruments and the managing agencies and, finally, we draw some general conclusions and we look at the main change events during this period. The reader should be aware that the quality of the historical data is not always as good as for more recent years and thus some care is needed in the interpretation of the results.

\section{Level of project funding}

All countries considered show a considerable increase in the volume of project funding over the last 30 years, but with some differences among them. In Figure 4, we present the evolution both in absolute terms (using GDP deflators) and as a percentage of GDP; this last is the simplest relative measure, since time series of total public funding of research (measured as gross expenditure on research and
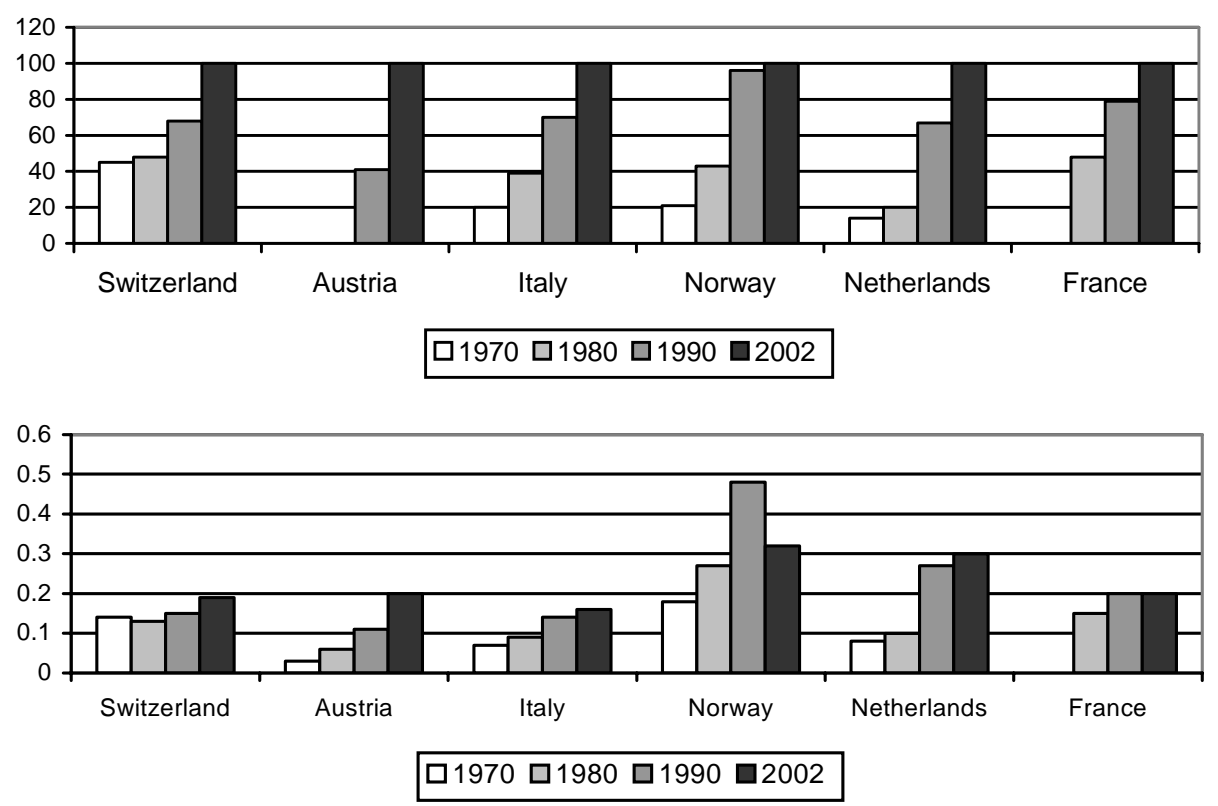

Figure 4. Evolution of project funding in real terms $(2002=100)$ and as $\%$ of GDP

Notes: Italy: 1970 refers to 1971 (first year available)

France: 1980 refers to 1982 (first year available)

Netherlands: 1970 refers to 1975 (first year available) 
development by government (GERD GOV) in the $\mathrm{R} \& \mathrm{D}$ statistics) are not very reliable over such a long period (Lepori, 2006b).

These data show an overall strong increase in the volume of project funding, both real and measured as a percentage of GDP. Since there is some evidence that public research funding did not strongly increase during these 30 years as a percentage of GDP, we can assume that the trend of increasing share of project funding is robust. In our sample, we can, however, identify different tendencies. In 1970, Norway and Switzerland had a significantly higher level of project funding (as a percentage of GDP) than the other countries; this can probably be related to the strength of the research councils system already created in the early post-war period (1952 for the Swiss National Science Foundation (Lepori, 2006a); between 1946 and 1949 for the Norwegian Research Councils (Skoie, 2000)).

In Austria, the main funding agencies (the Austrian Science Fund and the Austrian Innovation Agency) were established in 1967, while the main managing agency in the Italian case (the Ministry of Education and Research) was created only in the 1970s, and clearly the building up of a project funding system took place only from then. According to some available data, it seems that a similar evolution took place in Spain and Portugal during the 1980s and the 1990s (Sanz et al, 2005). Finally, in the French case, only the reforms at the beginning of the 1990s substantially modified a system based on institutional funding of public research through CNRS and joint technological programmes with public companies, to a system with a more important component of project funding (Thèves et al, 2007a).

\section{Diversification of instruments}

A general trend across countries has been a strong increase in the number of project funding instruments starting generally in the 1970s. This is displayed by an increase in the overall number of instruments (as shown by all country reports), but also in the number of significant instruments. In Figure 5, we measured this development by counting the number of instruments covering more than $5 \%$ of the total project funding volume.

Even if the data are to some extent problematic, the overall trend is robust: while in 1970 in most countries there were only two to three instruments covering more than $5 \%$ of the total funding volume, in 2002 this number was of eight to nine in most countries. The Dutch case shows a very high fragmentation, but this is largely because of a stronger disaggregation of the available data and structure (for example, with specific sectoral programmes for academic research).

Looking at the new instruments, there have been two dominant catalysts of this differentiation: the emergence of more specialised funds to answer to specific needs, either to promote specific research domains (such as technology, agriculture or health) or to answer to policy needs (especially for industry support and innovation) and the creation of European funding instruments. The main development model has thus been the addition of new instruments either to answer to new policy needs or as an effect of the emergence of new actors at the international level.

We notice that this process has been enabled by the strong increase in the overall volume of project funding, where additional funds have been provided for new instruments, while at the same time the budget of existing instruments increased.

\section{Changes in the portfolio}

Changes in the portfolio are also a major point of interest, since the shifts in policy rationales are well documented in the literature on research policy (Elzinga and Jamison, 1995; Guston, 2000). Our methodology allows some quantitative comparisons to be made over the last 30 years, even with the limitation that we disregard for the moment changes in the objectives and allocation criteria inside the same instruments (see Potì and Reale (2007, this issue) for a more detailed discussion). Figures 6 and 7 show the share of academic-oriented instruments and, jointly, the share of thematic instruments.

The figures show a common trend for the countries for which we have data, namely a strong increase of thematic instruments replacing progressively the academic instruments (even if, in real terms, these

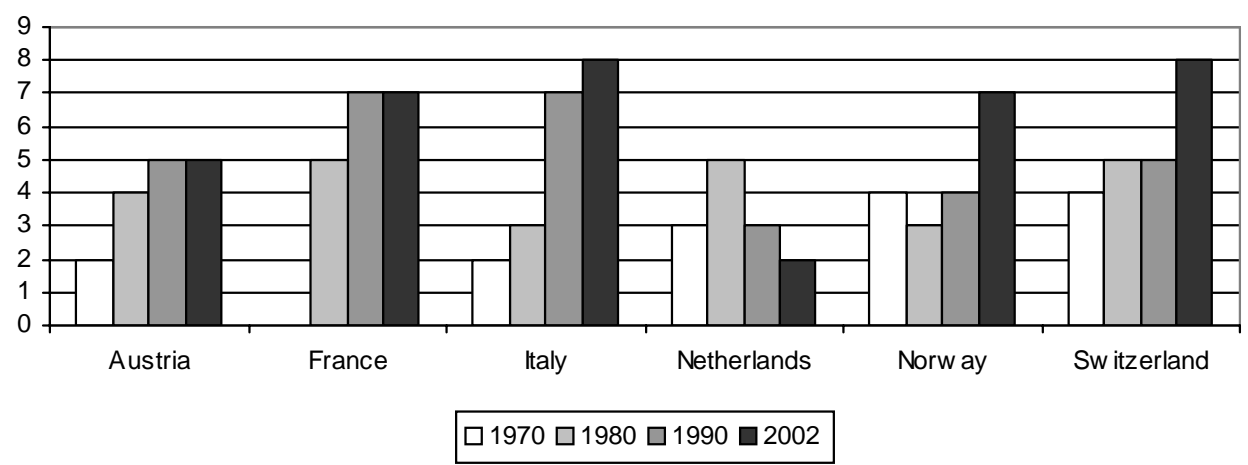

Figure 5. Diversification of project funding instruments

Notes: Number of instruments with a share $>5 \%$ of the total volume of project funding

ESA and EU FP and public administration contracts are considered as a single instrument 


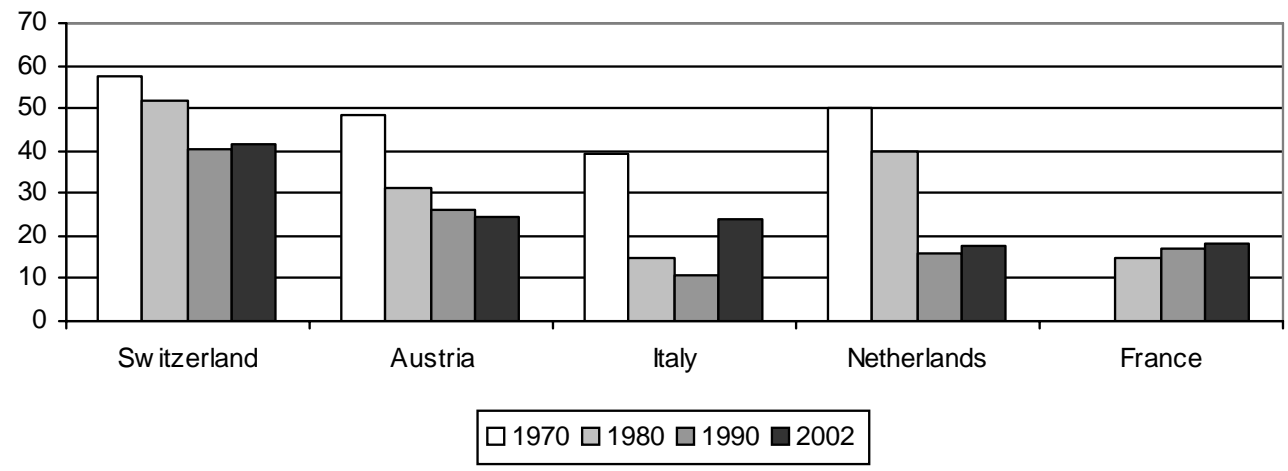

Figure 6. Share of academic-oriented instruments by country 1970-2002

Notes: $\quad$ Netherlands, 1970 refers to 1975; Italy, 1970 refers to 1971; France, 1980 refers to 1982

instruments have also continued to increase) in the portfolio. This confirms quantitatively the trend identified in the literature on research policy.

However, we notice also that the different countries move largely on parallel trajectories, where the differences between them do not decrease and, finally, end up in quite different positions in the diagram. Thus, given the composite nature of research policies and research funding systems, the existence of similar trends across countries is compatible with keeping strong national specificities. In a sense, we argue that the composite model has proved flexible enough to respond to general tendencies of research policy (largely defined internationally) and at the same time to take national specificities into account.

A final remark concerns the fact that most of this change occurred in the 1970s and 1980s, while the 1990s have been characterised by greater stability or, even, by an increase in the share of academic instruments, a turn that is, for example, well-documented in the Swiss case (Lepori, 2006a). For the moment, it is not fully clear to what extent this has to be seen as a new policy shift back to the support of basic research (as initiatives such as the creation of a European research council could indicate) and whether this shift will be durable, but the last decade clearly did not continue the trend towards the 'useful science' of the 1970s and of the 1980s.

\section{Stability and change in the managing authorities}

A look at the managing agencies displays a complex pattern, where not only national specificities are largely prevalent, but also each country seems to follow quite different paths.

Thus, in Switzerland, the SNF (the Swiss National Science Foundation) constructed its monopoly on project funding during the 1960s and to a large extent kept its role until today, still accounting for twothirds of the total volume of project funding at the national level. Actually, the SNF felt a strong pressure to change its structures and priorities during the 1970s, but succeeded in avoiding major changes or

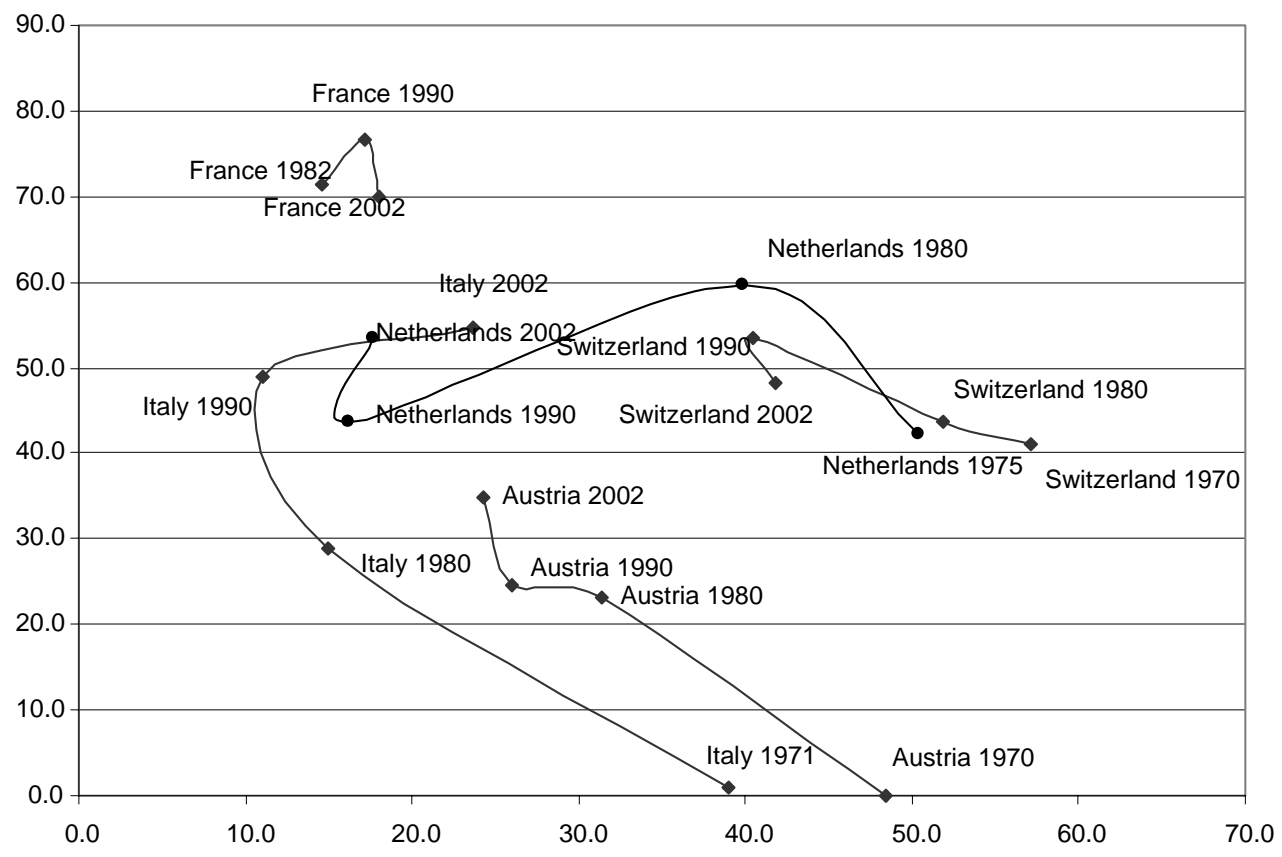

Figure 7. Share of instruments types by country 1970-2002

Notes: $\quad X$ axis: share of academic-oriented instruments

$Y$ axis: share of thematic-oriented instruments

The difference from $100 \%$ is accounted for with innovation-oriented instruments 
the creation of competing agencies by accepting to manage jointly with the public administration some policy-oriented and, later, technology-oriented programmes (Lepori, 2006a).

However, these programmes never took a large share in its funding volume and the SNF avoided a major reorganisation and change of its objectives; its original academic orientation was reinforced with the revision of the statutes in 2000, excluding political representatives from its main decision-making body (Slipersæter et al, 2007, this issue).

In Austria, the two funding agencies created in 1967 still largely keep their role and organisation and dominate project funding. Thus, the Austrian Science Fund maintains its role as funder of academic bottom-up projects with limited organisational change and, while other instruments have been launched, in 2002, individual research projects still accounted for three-quarters of total funding volume. Bottom-up project funding has also remained the dominant funding instrument for the industry sector throughout the last three decades and the Austrian Research Promotion Agency created in 2004 kept the former FFF industrial research grant scheme as the main pillar of the programme portfolio.

However, since the mid-1980s, alternative research and innovation promotion schemes different from bottom-up project funding have been introduced, for instance, the Kplus competence centres programme (launched in 1998) and the Christian Doppler Laboratories (since 1989) target science and industry co-operations in a new institutional manner. Furthermore, thematic targeted research programmes have been launched by ministries addressing specific issues such as genomics research, and the information society. Thus, rigidity of the funding agencies was overcome with an increase in the thematic programmes directly managed by the ministries.

In Norway, the situation was characterised by four or five research councils during the 1970s and 1980s before a major restructuring in 1993 (Slipersæter et $a l, 2007$, this issue). The two main research councils, The Norwegian Research Council for Science and the Humanities (NAVF), which mainly served academic research within all domains, and The Royal Norwegian Council for Scientific and Industrial Research (NTNF), mainly serving innovation and industry-relevant research, were both established in the early post-war period. So was a smaller specialised council for agricultural research. In 1972, came a specialised council for research related to fisheries, while another for applied social research was established in 1987 (Skoie, 2000).

In 1993, the former councils were merged into The Research Council of Norway, which was given the responsibility for a very large portfolio of instruments, targeting the full spectrum of disciplines as well as applied research and innovation. The portfolio of instruments reflects the broad responsibility, as the council maintains traditional projects and grants as well as centres of excellence, centres of innovation and large programmes for industrial research. Thus, the Norwegian case is unique in the European context for the degree of centralisation of project funding and for the depth of the reform during the 1990s (see Skoie (2000) for a detailed account).

The Italian situation is different in that Italy never possessed a strong research council; even at the beginning of the 1970s, with a very low level of project funding, the CNR (the Italian National Research Council) was not dominant and, actually, its funding agency role was always secondary with respect to its main role as a public research organisation (Potì and Reale, 2005b). Thus project funding was from the beginning developed inside the Ministry of University and Research through the creation of expert committees. At the same time, the Italian case has been characterised by a stronger instability concerning the funding volume and instruments, which have been repeatedly modified.

In the Netherlands, in the 1970s, project funding was managed mainly by the Research Council in a responsive mode. In the early 1990s NWO (Netherlands Organisation for Scientific Research) was reorganised into a more proactive council that had to manage thematic programmes as well. Since then, it has developed a range of funding instruments, especially different forms of programmatic funding and career support grants. The other main authority of project funds is the Ministry of Economic Affairs, which has a non-autonomous agency (SENTER/ NOVEM) for managing the range of innovation instruments. The project funds cover a range of different types of instrument, of which some are generic and others thematic, and that may address either academic research, public research institutes or firms or aim to create collaborative projects.

France has followed a complex path from a system dominated by a very large PRO - CNRS towards a system more similar in the organisation of the research system and in the allocation of funding to the other European countries. However, this has been done, not by the creation of new agencies, but by a progressive reshaping of the existing structures and allocation mechanisms, with the model of the joint laboratories between university and CNRS from one side, and with an allocation model for CNRS funds through the (competitive) labelling of the joint laboratories and the allocation to them of human resources rather than funds (Thèves et al, $2007 \mathrm{~b}$, this issue). The resulting model is a mix between the features of the allocation model based on project funding on one hand and (historicallyrelated) national specificities on the other.

A major common tendency in these countries has been the emergence of international agencies - the European Space Agency and later the European Union - as major players also in quantitative terms. As Figure 8 shows, their share in project funding is between $15 \%$ and $20 \%$ for large European countries and even more for small countries (with the 


\section{A major common tendency in these countries has been the emergence of international agencies, the European Space Agency and the European Union, as major players also in quantitative terms: their share in project funding is between 15 and $20 \%$ for large European countries and even more for small countries (except for Norway)}

exception of lower rates in Norway). If we consider future developments, such as the creation of a European Research Council, which will also enter into the funding of academic research (Dinges and Lepori, 2006), as well as the continuous increase of the EU Framework Programmes budget, it is not unlikely that, in the medium term, the European level will become more important for project funding than the national level. Clearly, this would represent a major structural change in research funding allocation.

\section{Conclusions}

Coming back to our research questions, the main outcome of this analysis is the display of a complex pattern of similarities and of differences among the countries considered. Thus, looking at today's level and organisation of project funding, we could say that all the countries considered in our sample have evolved during the last few decades towards a model in which project funding is the second major allocation mechanism for public research funding, accounting for between a quarter and a third of the total funding volume (even more in the Norwegian case), and in which basically there is a composite mix of policy objectives and instruments. We also find a number of similarities in the instruments used, such as centres of excellence, large programmes within the fields of information technology, genetics, nano-tech and so on that most countries seem to maintain.

However, this composite model leaves room for national specificities concerning the share of the different instrument types, as well as for maintaining instruments reflecting national needs and production, as in the case of Norway fisheries, oil and gas, polar environments, or, in the case of France, space research. Moreover, there are strong differences in the orientation towards different beneficiary groups, from $70 \%$ of project funding going to the highereducation sector in Switzerland, to more than $50 \%$ to the private companies in Italy, which seem to be explained by the orientation of national policies, but also by the diversity in the organisation of the research systems.

National specificities are definitely strongest for the managing structures, where each of the countries considered is an individual case, with its own specific organisation that can be explained largely by characteristics of the national political systems and by history. Thus, different organisational models are compatible with the overall policy rationale for project funding at international level. This includes, for example, the choice between creating independent agencies and managing project funding through ministries, or between having specialised agencies such as the Swiss National Science Foundation and a generalist research council as in Norway. The choice of the organisational model is likely to have an influence on allocation of funds, for example, according to our data, the presence of a research council tends to increase the share of academic instruments.

We consider that it was exactly the fuzziness of concepts, such as project funding, funding agency, policy-oriented instruments, and the acceptance that national interpretations of these concepts are legitimate, that made it possible to adopt them as an overall policy rationale shared among different countries, but accommodating, at the same time, national specificities in their implementation. It is sufficient to think of how the concept of a funding agency has

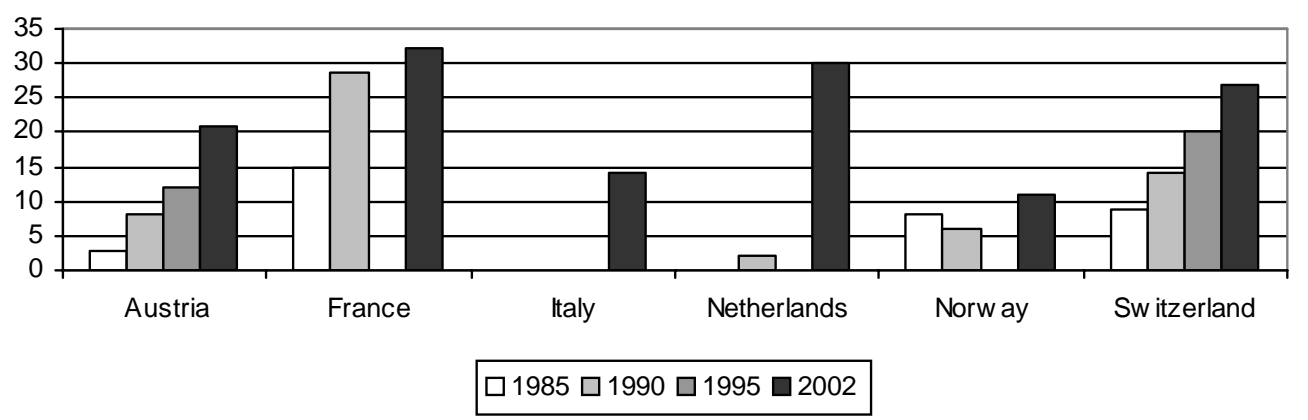

Figure 8. Share of international programs (ESA+EU FP)

Notes: $\quad$ France: 1985 data refer to 1982

Norway: Data specifies EU only from 1997; data in the figure includes all funding from abroad,

EU included; 1995 omitted because of poor data 
been stretched to include CNRS funding of joint laboratories in France. In a sense, in the context of quite different national systems, a concept cannot be too precise and well-defined (especially in operational terms) if it wants to be adopted as a general policy framework across countries.

Secondly, if we look to the evolution during the last three decades, we can identify some common tendencies: the overall increase of the share of project funding in overall public funding; a large increase in the number of instruments; the emergence of European agencies; and a general shift from responsive mode to instruments where thematic priorities are defined from the beginning (with, however, a reversal of this trend in the late 1990s). However, this does not imply that national differences disappear, but individual countries largely keep a distinct profile exactly because the prevailing model is flexible enough to accommodate for national specificities.

This fact is particularly evident concerning the funding agencies, where each country essentially followed an evolutionary path based on the reshaping of existing managing structures and, to some extent, on the addition of new instruments alongside the existing ones. Thus, organisations like research councils display a high degree of resilience in face

\section{References}

Arthur, W 1994. Increasing Returns and Path Dependence in the Economy. Ann Arbor: University of Michigan Press.

Benner, $M$ and $U$ Sandström 2000. Institutionalizing the triple helix: research funding and norms in the academic system. Research Policy, 29(2), 291-301.

Braun, D 1998. The role of funding agencies in the cognitive development of science. Research Policy, 27(8), 807-821.

Braun, D 2003. Lasting tensions in research policy-making - a delegation problem. Science and Public Policy, 30(5), 309-321.

Braun, D 2006. Delegation in distributive policies. In Delegation in Contemporary Democracies, eds. D Braun and F Gilardi, pp. 146-170. London: Routledge.

Braun, D and M Benninghoff 2003. Policy learning in Swiss research policy - the case of the National Centres of Competence in Research. Research Policy, 32(10), 1849-1863.

Braun, D and D Guston 2003. Principal-agent theory and the research policy: an introduction. Science and Public Policy, 30(5), 302-308.

Braun, D, M Benninghoff, R Ramuz and J-Ph Leresche 2003. Learning capacities in public-funded research systems. Research report, Lausanne.

Brooks, H 1986. National science policy and technological innovation. In The Positive Sum Strategy: Harnessing Technology for Economic Growth, eds. R Landau and N Rosenberg, pp. 119-168. Washington DC: The National Academies Press.

Caracostas, $P$ and $U$ Muldur 2001. The emergence of a new European Union research and innovation policy. In Research and Innovation Policies in the New Global Economy: an International Comparative Analysis, eds. P Larédo and P Mustar, Cheltenham: Edward Elgar.

Crouch, C and H Farrell 2004. Breaking the path of institutional development? Alternatives to the new determinism. Rationality and Society, 16(1), 5-43.

David, P 1985. Clio and the economics of QWERTY. The American Economic Review, 72(2), 332-337.

di Maggio, P 1991. Constructing an organizational field as a professional project: US art museums 1920-1940. In The New Institutionalism in Organizational Analysis, eds. W Powell and P of a changing environment, but this does not exclude profound changes and restructuring.

In our sample, both cases of institutional reforms are present: Norway displays a case for revolutionary change, where the whole organisation of project funding has been reshaped with the merger of research councils, while France is a case for evolutionary change, where the transition from the organisation of the public research system based on direct funding of laboratories towards an higher-education based system with large project funding has not been achieved by disrupting the existing institutions, but by careful institutional engineering and changes of internal rules.

At the same time, imitation and transfer of models borrowed from other countries has taken place largely at the moment of the creation of new agencies (think of the diffusion of the research council model in the early post-war period) or of new instruments (think of the centres of excellence programmes), but also played a role in the restructuring of existing agencies and instruments (think of the French case). Models of change seem thus to be largely bound to characteristics of the national institutional framework (especially of the political system), as the extremely stable Swiss case clearly displays.

di Maggio, pp. 267-292. University of Chicago Press: Chicago and London.

Dinges, M 2005. Project Funding. Austria. Country Report. Paris: European Network of Indicators Producers.

Dinges, M and B Lepori 2006. Public project funding of research activities. National differences and implications for the establishment of a European Research Council. Paper presented at the Conference New Frontiers in Evaluation, Vienna, 25-26 April.

Dominguez Lacasa, I, H Grupp and U Schmoch 2003. Tracing technological change over long periods in Germany in chemicals using patent statistics. Scientometrics, 57(2), 175-195.

Dosi, Giovanni 1982. Technological paradigms and technological trajectories: a suggested interpretation of the determinants and directions of technical change. Research Policy, 11, 147-162.

Elzinga, A and A Jamison 1995. Changing policy agendas in science and technology. In Handbook of Science and Technology Studies, eds. S Jasanoff, G E Markle, J C Petersen and T J Pinch, pp. 572-597. London: Sage.

Geuna, A 2001.The changing rationale for European university research funding: are there negative unintended consequences? Journal of Economic Issues, 35(3), 607-632.

Godin, B, M Trépanier and M Alber 1999. Des organismes sous tensions: les conseils subventionnaires et la politique scientifique. Sociologie et Société, 32(1), 3-27.

Granovetter, M 1985. Economic action and social structure: the problem of embeddedness. American Journal of Sociology, 91, 481-510.

Grupp, H, I Dominguez Lacasa, M Friedrich-Nishio and A Jungmittag 2004. Innovation and growth in Germany in the past 150 years. In Entrepreneurship, the New Economy and Public Policy, eds. U Cantner, E Dinopoulos and R F Lanzillotti, pp. 267-289. Berlin: Springer.

Guston, D 1996. Principal-agent theory and the structure of science policy. Science and Public Policy, 23(4), August, 229-240.

Guston, D 2000. Between Politics and Science: the Integrity and Productivity of Research. Cambridge: Cambridge University Press.

Hollingsworth, J R 2002a. On institutional embeddedness. In Advancing Socio-Economics: an Institutionalist Perspective, eds. J R Hollingsworth, K Müller and E J Hollingsworth, pp. 87-108. New York: Rowman and Littlefield. 
Hollingsworth, J R 2002b. On multi-level analysis. In Advancing Socio-Economics: an Institutionalist Perspective, eds. J R Hollingsworth, K Müller and E J Hollingsworth, pp. 19-36. New York: Rowman and Littlefield.

Kuhlmann, S 2001. Governance of innovation policy in Europe three scenarios. Research Policy, 30(6/2001), 953-976.

Larédo, P and P Mustar 2001. Research and Innovation Policies in the new Global Economy. An International Comparative Analysis. Cheltenam: Edward Elgar.

Lemola, T 2002. Convergence of national science and technology policies: the case of Finland. Research Policy, 31(8-9), 1481-1490.

Lepori, B 2005. Project funding. Switzerland. Country Report. Paris: European Network of Indicators Producers.

Lepori, B 2006a. Public research funding and research policy: a long-term analysis for the Swiss case. Science and Public Policy, 33(3), April, 205-216.

Lepori, B 2006b. Methodologies for the analysis of research funding and expenditure: from input to positioning indicators. $R e$ search Evaluation, 15(2), August, 133-143.

Lepori, B, P van den Besselaar, M Dinges, B van der Meulen, B Potì, E Reale, S Slipersæter and J Thèves 2008. Indicators for comparative analysis of public project funding. concepts, implementation and evaluation. Research Evaluation, 17(1), March, forthcoming.

Mahoney, J 2000. Path dependence in historical sociology. Theory and Society, 29(4), 507-548.

Meyer, J, R Scott, D Strang and A Creighton 1988. Bureaucratization without centralization: changes in the organizational systems of U.S. public education 1940-1980. In Institutional Patterns and Organizations: Culture and Environment, ed. L Zucker, pp. 139-168. Cambridge MA: Ballinger.

Meyer-Kramer, F and G Reger 1999. New perspectives on the innovation strategies of multinational enterprises: lessons for technology policy in Europe. Research Policy, 28, 751-776.

Millar, J and J Senker 2000. International approaches to research policy and funding: university research policy in different national contexts. Brighton: SPRU.

Mustar, $P$ and $P$ Larédo 2002. Innovation and research policy in France (1980-2000) or the disappearance of the Colbertist state. Research Policy, 31(1), 55-72.

National Science Foundation 2003. National patterns of research and development resources: 2002 data update. Washington DC: NSF.

North, D 1990. Institutions, Institutional Change and Economic Performance. Cambridge: Cambridge University Press.

OECD, Organization for Economic Co-operation and Development 2002. Frascati Manual: Proposed Standard Practice for Surveys on Research and Experimental Development. Paris: OECD.

OECD, Organization for Economic Co-operation and Development 2003. Governance of Public Research: Towards Better
Practices. Paris: OECD.

Pierson, $P$ 2000. Increasing returns, path dependence and the study of politics. The American Political Science Review, 94(2), 251-267.

Potì, B and E Reale 2005a. Project funding. Italy. Country report. Paris: European Network of Indicators Producers.

Potì, B and E Reale 2005b. Changing patterns in public allocation for R\&D: composition and evolution of Government project funding in Italy. Paper presented at the Workshop on S\&T Indicators Production, Lisbon, 22-23 September.

Potì, B and E Reale 2007. Government and R\&D allocation policies: an empirical exploration of changes in delegation and evaluation modes. Science and Public Policy, 34(6), July, 417-430.

Powell, W and P di Maggio 1983. The iron cage revisited: Institutional isomorphism and collective rationality. American Sociological Review, 48, April, 147-160.

Sanz, L, L Cruz and T Santos Pereira 2005. Quasi-intermediary agencies? The development of research councils in Portugal and Spain. Paper presented at the Workshop on S\&T Indicators Production, Lisbon, 22-23 September.

Scott, R W 2001. Institutions and Organizations. Thousands Oaks CA: Sage.

Scott, R W, M Ruef, P Mendel and C Caronna 2000. Institutional Change and Healthcare Organizations. Chicago: The University of Chicago Press.

Senker, J et al 1999. European Comparison of Public Sector Research Systems. Brighton: SPRU.

Shove, E 2003. Principals, agents and research programmes. Science and Public Policy, 30(5), October, 371-381.

Skoie, H 2000. Diversity and identity: the merger of five research councils in Norway. Science and Public Policy, 27(2), April, 83-93.

Slipersæter, S 2007 Project Funding. Norway. Country Report. Paris: European Network of Indicators Producers.

Slipersæter, S, B Lepori and M Dinges 2007. Between policy and science: research councils' responsiveness in Austria, Norway and Switzerland. Science and Public Policy, 34(6), July, 401-415.

Thèves, J, G Filliatreau and B Lepori 2007a. Project Funding. France. Country Report. Paris: European Network of Indicators Producers.

Thèves, J, B Lepori and $P$ Larédo 2007b. Changing patterns of public research funding in France. Science and Public Policy, 34(6), July, 389-399.

van der Meulen, B 2003. New role and strategies of a research council: intermediation of of the principal-agent relationship. Science and Public Policy, 30(5), October, 323-336.

van den Besselaar, P, R Memphuis and B van der Meulen 2007. Project Funding. Netherlands. Country Report. European Network of Indicators Producers, Paris. 